\title{
Pengembangan Media Pembelajaran Berbasis E-Learning Pada Mata Kuliah Fisika Modern
}

\author{
Wiwik Widyawati, Sahrul Saehana, dan Unggul Wahyono \\ Wiwikwidyaalgozali13@gmail.com \\ Program Studi Pendidikan Fisika FKIP Universitas Tadulako \\ Jl. Soekarno Hatta Km. 9 Kampus Bumi Tadulako Tondo Palu - Sulawesi Tengah
}

\begin{abstract}
Abstrak - Tujuan dari penelitian ini adalah untuk menghasilkan media pembelajaran berbasis e-learning pada mata kuliah fisika modern guna meningkatkan minat belajar mahasiswa. Permasalahan dari penelitian ini adalah Bagaimana mengembangkan media pembelajaran berbasis e-learning pada mata kuliah fisika modern?. Untuk mengetahui tingkat kelayakan media pembelajaran tersebut maka dilakukan uji kelayakan terhadap produk. Uji kelayakan yang dilakukan terhadap produk terbagi menjadi tiga, uji kelayakan materi, uji kelayakan media, dan uji respon mahasiswa. Berdasarkan hasil uji materi yang dilakukan diperoleh skor rata-rata sebesar 3,72 dan dikategorikan sangat baik, hasil uji media yang dilakukan diperoleh skor rata-rata sebesar 3,25 dan dikategorikan baik. Hasil analisis penilaian respon mahasiswa yang dilakukan terhadap dua puluh mahasiswa kelas $A$ semester $V$ program studi pendidikan fisika FKIP Universitas Tadulako diperoleh skor rata-rata sebesar 3,16 dan dikategorikan setuju. Hasil penelitian menunjukan media pembelajaran berbasis e-learning yang dikembangkan dapat dijadikan sebagai salah satu media pembelajaran yang dapat menunjang proses pembelajaran mahasiswa.
\end{abstract}

Kata Kunci: Media Pembelajaran, E-Learning

\section{PENDAHULUAN}

Ilmu Pengetahuan dan Teknologi (IPTEK) pada saat ini telah berkembang dengan pesat. Perkembangan teknologi informasi dan komunikasi (TIK) saat ini telah membawa berbagai perubahan dalam kehidupan manusia. Perkembangan tersebut semakin dirasakan di berbagai sektor, utamanya di bidang pendidikan.

Menurut Oetomo dan Priyogutomo (2004), pendidikan merupakan suatu proses komunikasi dan pertukaran informasi dari pendidik ke peserta didik yang terkait dengan pendidikan, yang memiliki unsur-unsur pendidik sebagai sumber informasi, media sebagai sarana penyajian ide, gagasan dan materi pendidikan serta peserta didik itu sendiri [1].

Perkembangan dunia pendidikan pada saat ini, merupakan tantangan untuk mengembangkan kemampuan dalam dunia pendidikan. Perkembangan dunia pendidikan tidak lepas dari proses belajar mengajar yang efektif. Proses belajar mengajar ditandai dengan interaksi antara guru sebagai pentransfer materi dan siswa sebagai penerima materi. Terjadinya interaksi dan komunikasi yang baik dapat mewujudkan suasana belajar yang dinamis. Interaksi edukatif merupakan salah satu bentuk interaksi yang didalamnya berlangsung suatu proses interaksi dalam satu ikatan untuk mencapai tujuan pendidikan dan pengajaran.

Pada umumnya dalam kegiatan pembelajaran tenaga pendidik hanya menggunakan bahan ajar cetak, misalnya buku cetak atau buku teks.
Namun, dalam kegiatan pembelajaran dengan menggunakan bahan ajar cetak memiliki kelemahan yaitu pemaparan materi bersifat linear, kegiatan pembelajaran terpusat pada pengajar, materi ajar yang disajikan dalam bentuk bahasa yang sulit dimengerti oleh peserta didik dan bentuk informasi disajikan dalam bentuk terbatas yaitu dalam bentuk teks dan gambar. Setiap materi pembelajaran mempunyai tingkat kesukaran yang bervariasi. Materi pembelajaran yang mempunyai tingkat kesukaran yang tinggi tentu sukar dipahami oleh peserta didik, apalagi oleh peserta didik yang kurang menyukai materi pembelajaran yang disampaikan. Oleh karena itu, diperlukan media sebagai alat bantu dalam proses pembelajaran dengan tujuan untuk meningkatkan efektifitas dan kualitas pembelajaran.

Salah satu cara meningkatkan efektifitas dan kualitas pembelajaran yaitu dengan memanfaatkan teknologi pada sistem pembelajaran jarak jauh melalui belajar secara elektronik atau yang lebih dikenal dengan istilah e-learning. E-learning merupakan singkatan dari Electronic Learning (pembelajaran elektronik), e-learning juga bisa diartikan sebagai pembelajaran melalui media elektronik. Melalui e-learning materi pembelajaran dapat diakses kapan saja dan dari mana saja, disamping itu materi dapat diperkaya dengan berbagai sumber belajar termasuk multimedia dengan cepat dapat diperbaharui oleh pengajar.

Media pembelajaran e-learning merupakan media pembelajaran yang dikembangkan saat 
ini. Penelitian serupa juga pernah dilakukan oleh Syarif (2012) yang mengembangkan media pembelajaran e-learning berbasis WEB, menyimpulkan bahwa penelitian yang telah dikembangkan layak untuk diproduksi dan digunakan di sekolah-sekolah dengan fasilitas yang mendukung [2]. Hidayat (2008) menyimpulkan bahwa ada perbedaan yang signifikan antara hasil belajar siswa yang menggunakan e-learning dalam proses pembelajaran dengan hasil belajar siswa yang menggunakan cara konvensional dalam proses pembelajaran [3]. Dalam hal ini, peningkatan motivasi belajar secara signifikan ditemukan pada siswa yang menggunakan e-learning dalam proses pembelajaran. Dari hasil penelitian dapat dirumuskan bahwa ada korelasi yang signifikan antara motivasi dengan peningkatan hasil belajar pada siswa menggunakan e-learning.

Media pembelajaran adalah alat, metode dan teknik yang digunakan dalam rangka lebih mengefektifkan komunikasi dan interaksi antara guru dan siswa dalam proses pendidikan dan pengajaran di sekolah [4]. Hal ini sependapat dengan Sudjana (2002) yang menyatakan bahwa media pembelajaran merupakan alat bantu mengajar, yaitu untuk menunjang penggunaan metode mengajar yang digunakan oleh guru. Dengan adanya media pembelajaran berbasis e-learning, peserta didik dengan mudah memahami apa isi materi dari suatu pelajaran tersebut. Hal ini sesuai dengan definisi media pembelajaran itu sendiri [5]. Penelitian Palupessy (2014) menunjukkan bahwa media memiliki kualitas yang baik dan sangat layak untuk digunakan sebagai media pembelajaran fisika I [6].

E-learning merupakan aplikasi internet yang dapat menghubungkan antara pendidik dan peserta didik dalam sebuah ruang belajar online [7]. E-learning ternyata untuk mengatasi keterbatasan antara pendidik dan peserta didik, terutama dalam waktu dan ruang. Jadi tidak harus berada dalam satu dimensi waktu dan ruang, artinya bisa kapan saja. Pemanfaatan media pembelajaran berbasis e-learning dalam proses pembelajaran memungkinkan pendidik dan peserta didik dapat berkomunikasi secara mudah dan cepat melalui fasilitas internet tanpa dibatasi oleh jarak, tempat, dan waktu. Media ini juga berperan dalam menumbuhkan kreativitas peserta didik dalam mempelajari ilmu pengetahuan.

Fisika modern merupakan salah satu mata kuliah penting untuk mahasiswa program studi pendidikan fisika. Mata kuliah ini membahas konsep-konsep yang dikembangkan di abad 20, dimana perumusan-perumusan dalam fisika klasik tidak lagi mampu menjelaskan fenomena- fenomena yang terjadi pada materi dengan skala atomik atau subatomik dan partikel yang bergerak dengan kecepatan mendekati kecepatan cahaya. Mahasiswa perlu memahami materi tersebut dengan baik dan benar, sebagai langkah awal untuk memahami tingkat ilmu yang lebih tinggi seperti fisika kuantum, fisika statistik, pendahuluan fisika zat padat dan pendahuluan fisika inti. Materi fisika modern yang karakteristik materinya didominasi oleh konsep abstrak dan mikroskopik apabila diajarkan secara teoritis tanpa didukung contohcontoh yang membuatnya lebih maksimal seperti dengan bantuan animasi dan video dapat menimbulkan perbedaan pemahaman pada mahasiswa. Sumber belajar yang digunakan berupa buku referensi dan bahan ajar dari dosen dirasa belum cukup untuk memahami materi fisika modern dan sebagai sumber belajar mandiri di luar kelas. Sementara itu, ruang perkuliahan program studi pendidikan fisika dilengkapi dengan fasilitas hotspot. Namun, fasilitas ini belum termanfaatkan secara maksimal oleh mahasiswa. Mahasiswa belum memanfaatkan internet sebagai salah satu sumber belajar.

Gambaran kondisi tersebut menunjukkan pentingnya menyediakan media pembelajaran yang praktis, jelas dan menarik sehingga mampu meningkatkan minat belajar mahasiswa. Oleh karena itu, tujuan dari penelitian ini adalah mengembangkan suatu media pembelajaran berbasis e-learning yang dilengkapi materi, video, simulasi, dan forum diskusi yang dapat membantu mahasiswa dalam belajar. Berdasarkan uraian tersebut, penulis tertarik untuk melakukan suatu penelitian tentang "Pengembangan Media Pembelajaran Berbasis E-Learning Pada Mata Kuliah Fisika Modern".

\section{METODE PENELITIAN}

Penelitian ini termasuk jenis penelitian dan pengembangan atau dikenal Research and Developement (R\&D) yaitu model penelitian yang digunakan untuk menghasilkan produk tertentu, dan menguji keefektifan produk tersebut [8]. Langkah-langkah penelitian secara umum dapat dilihat pada Gambar 1.

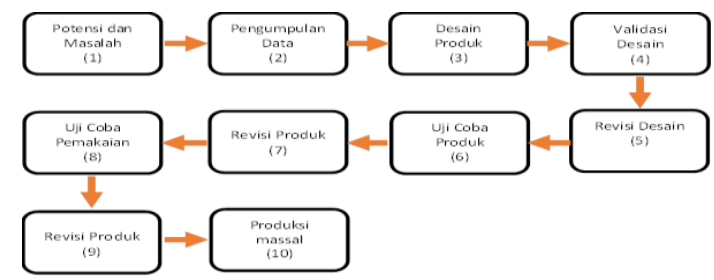

Gbr 1. Langkah-langkah metode Research and Development 
Langkah-langkah dalam penelitian ini penelitian hanya sampai pada tahap revisi produk. Dari gambar 1 maka langkah-langkah yang dilaksanakan meliputi:

\section{Potensi dan masalah}

Penelitian dapat diangkat dari adanya potensi atau masalah. Potensi adalah segala sesuatu yang apabila didayagunakan akan memiliki nilai tambah (Sugiyono, 2010). Sedangkan masalah adalah penyimpangan antara kenyataan dan harapan.

2. Pengumpulan data

Setelah potensi masalah disajikan secara faktual, selanjutnya akan dilakukan pengumpulan bahan-bahan yang diperlukan untuk membuat bahan ajar. Bahan-bahan yang dibutuhkan seperti gambar-gambar sebagai pelengkap dan lain sebagainya.

3. Desain produk

Setelah dikumpulkan berbagai macam data yang dibutuhkan, maka selanjutnya proses pembuatan desain. Proses ini adalah proses dimana gambaran awal dari bahan ajar yang akan kita buat. Pada penelitian ini akan dibuat demo produk yang akan dikembangkan.

4. Validasi desain

Validasi ini berguna untuk mengetahui apakah produk yang dibuat layak diujikan atau tidak. Validasi dilakukan melalui diskusi dengan ahli. Ahli disini adalah ahli media dan ahli materi yang berkompeten di bidangnya.

5. Revisi desain

Setelah melewati proses validasi, maka diketahui kelemahan-kelemahan demo produk yang dibuat. Kelemahan tersebut kemudian dikurangi dengan memperbaiki bagian-bagian yang dirasa masih kurang.

6. Uji coba produk

Langkah selanjutnya adalah dengan menguji coba produk, Uji coba dilakukan oleh mahasiswa semester $V$ (lima) Program Studi Pendidikan Fisika Universitas Tadulako.

7. Revisi produk

Langkah revisi merupakan langkah terakhir dari penelitian ini, dan setelah revisi maka produk sudah bisa digunakan. Selanjutnya penulisan laporan penelitian.

Penelitian ini dilaksanakan di Program Studi Pendidikan Fisika Fakultas Keguruan dan Ilmu Pendidikan Universitas Tadulako. Waktu pelaksanaan penelitian pengembangan ini dilakukan mulai bulan September 2016 s.d. Januari 2017. Subjek penelitian ini adalah seluruh mahasiswa semester $\mathrm{V}$ Program Studi Pendidikan Fisika. Penelitian ini adalah penelitian dan pengembangan dengan uji terbatas, maka hanya 20 mahasiswa yang diambil sebagai subjek penelitian untuk menilai kelayakan media pembelajaran.

Instrumen yang digunakan dalam penelitian ini adalah dengan teknik angket (Quesioner) bertujuan untuk mengukur kelayakan isi/materi dan media dalam pembelajaran. Angket diberikan kepada ahli materi, ahli media, dan mahasiswa sesuai kebutuhan dan tujuannya. Jenis data terdiri dari data kuantitatif dan kualitatif. Data kuantitatif berupa skor penilaian seluruh bagian dan isi bahan ajar berdasar hasil angket uji validitas dengan skala likert berupa angka 1, 2, 3 dan 4. Data kualitatif merupakan evaluasi dari validator (tanggapan, masukan, saran dan kritik) yang tercantum dalam angket maupun diskusi langsung yang digunakan sebagai pertimbangan dalam melakukan revisi terhadap media pembelajaran.

Teknik analisis yang digunakan untuk menganalisis data hasil validasi adalah perhitungan nilai rata-rata. Penentuan teknik analisis nilai rata-rata ini berdasarkan pendapat dari Arikunto (2006),[9] yang menyatakan bahwa untuk mengetahui peringkat nilai akhir pada setiap butir angket penelitian, jumlah nilai yang diperoleh dibagi dengan banyaknya responden yang menjawab angket penilaian tersebut. Rumus untuk menghitung nilai rata-rata adalah sebagai berikut.

$$
\bar{X}=\frac{\sum x}{n}
$$

Keterangan:

$\overline{\boldsymbol{X}} \quad$ : nilai rata-rata dalam tiap butir pernyataan

$\sum x$ : jumlah nilai dari seluruh penilaian dalam tiap butir pernyataan

$\boldsymbol{n}$ : jumlah butir pernyataan

Mengubah skor rata-rata yang diperoleh ke dalam bentuk kualitatif berdasarkan Tabel 1 [10].

TABEL 1 KRITERIA PENILAIAN PRODUK

\begin{tabular}{cc}
\hline Skor Rata-Rata & Kriteria \\
\hline $3,25<\bar{X} \leqslant 4,00$ & Sangat baik (SB) \\
$2,50<\bar{X} \leqslant 3,25$ & Baik (B) \\
$1,75<\bar{X} \leqslant 2,50$ & Kurang (K) \\
$1,00 \leqslant \bar{X} \leqslant 1,75$ & Sangat Kurang (SK)
\end{tabular}

Analisis data respon mahasiswa serupa dengan analisis kualitas penilaian produk. Rata-rata skor dari angket respon selanjutnya diubah ke dalam bentuk kualitatif berdasarkan Tabel 2 .

TABEL 2 KRITERIA KATEGORI RESPON MAHASISWA

\begin{tabular}{cc}
\hline Skor Rata-Rata & Kriteria \\
\hline $3,25<\bar{X} \leqslant 4,00$ & Sangat Setuju (SS) \\
$2,50<\bar{X} \leqslant 3,25$ & Setuju (S) \\
$1,75<\bar{X} \leqslant 2,50$ & Tidak Setuju (TS) \\
$1,00 \leqslant \bar{X} \leqslant 1,75$ & Sangat Tidak Setuju (STS) \\
\hline
\end{tabular}


p-ISSN 2338-3240, e-ISSN 2580-5924

Skor penilaian atau tingkat kelayakan baik setiap aspek maupun keseluruhan terhadap bahan ajar menggunakan Tabel 2, sebagai acuan penilaian data yang dihasilkan dari validitas ahli materi, ahli media, serta ujicoba pada mahasiswa agar mempermudah dalam pemberian suatu kriteria nilai bahwa media pembelajaran berbasis e-learning mata kuliah fisika modern yang dikembangkan sudah layak atau belum untuk digunakan.

\section{HASIL DAN PEMBAHASAN}

\section{A. Hasil Penelitian}

1. Uji ahli materi

Uji ahli materi dilakukan untuk memperoleh data dari ahli isi materi berupa data kualitatif dalam bentuk komentar dan saran terhadap isi materi fisika modern. Pada tahap uji kelayakan materi dilakukan oleh seorang dosen Fisika Fakultas Matematika dan Ilmu Pengetahuan Alam. Dari hasil validasi materi didapatkan hasil penilaian seperti pada Tabel 3.

TABEL 3 HASIL ANALISIS ANGKET UJI COBA AHLI MATERI FISIKA MODERN

\begin{tabular}{|c|c|c|c|}
\hline No & Pokok Bahasan & Skor & Kategori \\
\hline 1 & Pendahuluan & 3,33 & Sangat Baik \\
\hline 2 & Relativitas & 3,21 & Baik \\
\hline 3 & $\begin{array}{l}\text { Sifat partikel dari } \\
\text { gelombang }\end{array}$ & 4,00 & Sangat Baik \\
\hline 4 & $\begin{array}{l}\text { Sifat gelombang dari } \\
\text { partikel }\end{array}$ & 4,00 & Sangat Baik \\
\hline 5 & Model-model atom & 3,87 & Sangat Baik \\
\hline 6 & Mekanika kuantum & 3,81 & Sangat Baik \\
\hline 7 & $\begin{array}{l}\text { Teori kuantum atom } \\
\text { hidrogen }\end{array}$ & 3,53 & Sangat Baik \\
\hline 8 & berelektron & 4,00 & Sangat Baik \\
\hline \multicolumn{2}{|r|}{ Rata-Rata } & 3,72 & Sangat Baik \\
\hline & $\begin{array}{l}\text { Pokok bah } \\
\text { sebelum m }\end{array}$ & as di & $\begin{array}{l}\text { n pengantar } \\
\text { rmasi galileo }\end{array}$ \\
\hline
\end{tabular}

Adapun tingkat pencapaian yang diperoleh dari hasil penilaian angket uji coba ahli materi yang dihitung dengan menggunakan Persamaan 1, diperoleh jumlah nilai total sebesar 3,72 nilai tersebut menunjukkan bahwa materi termasuk dalam kategori sangat baik.

\section{Validasi ahli media}

Uji ahli media pembelajaran berbasis e-learning dilakukan dengan memperlihatkan desain media pembelajaran berbasis e-learning beserta angket kepada ahli media pembelajaran berbasis e-learning. Pada tahap uji kelayakan media dilakukan oleh seorang dosen Pendidikan Fisika. Hasil penilaian oleh ahli media dapat dilihat pada Tabel 4.
TABEL 4 HASIL ANALISIS ANGKET UJI COBA AHLI DESAIN MEDIA

\begin{tabular}{cccc}
\hline No & Aspek Penilaian & $\begin{array}{c}\text { Skor Rata- } \\
\text { Rata }\end{array}$ & $\begin{array}{c}\text { Kategori } \\
\text { Kualitas }\end{array}$ \\
\hline 1 & Tampilan Media & 3,42 & Sangat Baik \\
2 & Pembelajaran & 3,00 & Baik \\
3 & Pemograman & 3,43 & Sangat Baik \\
& Rata-Rata & 3,25 & Baik \\
\hline
\end{tabular}

Saran: karena hanya ada satu video, jadi perlu ditambah video pada pokok bahasan yang lainnya

Adapun tingkat pencapaian yang diperoleh dari hasil penilaian angket uji coba ahli media yang dihitung dengan menggunakan Persamaan 1, diperoleh jumlah nilai rata-rata sebesar 3,25 nilai tersebut menunjukkan bahwa media pembelajaran berbasis e-learning termasuk dalam kriteria baik.

\section{Hasil angket respon mahasiswa}

Pada tahap ini dilakukan uji coba terbatas di Program Studi Pendidikan Fisika Universitas Tadulako. Hasil uji coba yang dilakukan terhadap 20 mahasiswa semester $\mathrm{V}$ menunjukkan bahwa media pembelajaran berbasis e-learning layak untuk digunakan dalam proses pembelajaran fisika modern. Hal tersebut dapat dilihat pada Tabel 5.

TABEL 5 HASIL ANALISIS RATA-RATA PENILAIAN BERDASARKAN RESPON MAHASISWA

\begin{tabular}{|c|c|c|}
\hline \multicolumn{3}{|c|}{ BERDASARKAN RESPON MAHASISWA } \\
\hline NO & PERNYATAAN & $\begin{array}{l}\text { SKOR } \\
\text { RATA- } \\
\text { RATA }\end{array}$ \\
\hline \multicolumn{3}{|c|}{ Aspek Pembelajaran } \\
\hline 1 & $\begin{array}{l}\text { Media pembelajaran ini memuat judul } \\
\text { program pembelajaran yang jelas. }\end{array}$ & 3,45 \\
\hline 2 & $\begin{array}{l}\text { Penyajian materi dalam media } \\
\text { pembelajaran ini dimulai dari yang } \\
\text { mudah ke sukar atau secara } \\
\text { berurutan. }\end{array}$ & 3,1 \\
\hline 3 & $\begin{array}{l}\text { Media pembelajaran ini memberikan } \\
\text { kemudahan dalam memahami materi. }\end{array}$ & 3,25 \\
\hline 4 & $\begin{array}{l}\text { Materi dapat diulang setiap saat } \\
\text { sehingga dapat membantu saya untuk } \\
\text { meningkatkan daya ingat. }\end{array}$ & 3,3 \\
\hline 5 & $\begin{array}{l}\text { Media pembelajaran ini } \quad \text { memuat } \\
\text { pertanyaan-pertanyaan } \\
\text { mendorong saya untuk belajar }\end{array}$ & 3,1 \\
\hline 6 & 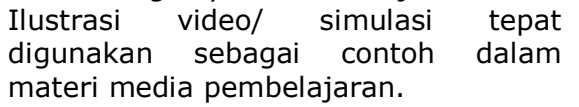 & 3,05 \\
\hline 7 & $\begin{array}{l}\text { Penyajian kuis dalam media } \\
\text { pembelajaran ini memberikan } \\
\text { kesempatan mengerjakan latihan } \\
\text { secara mandiri. }\end{array}$ & 3,15 \\
\hline 8 & $\begin{array}{l}\text { Dalam media pembelajaran ini } \\
\text { terdapat feedback jawaban benar/ } \\
\text { salah pada kuis. }\end{array}$ & 3,1 \\
\hline 9 & $\begin{array}{l}\text { Chatting yang terdapat pada media } \\
\text { pembelajaran ini membantu saya } \\
\text { dalam berkomunikasi antar sesama } \\
\text { pengguna. }\end{array}$ & 3,35 \\
\hline 10 & $\begin{array}{l}\text { Penyediaan forum diskusi pada media } \\
\text { pembelajaran ini dapat membantu }\end{array}$ & 3,25 \\
\hline
\end{tabular}


saya mendapatkan solusi dari beberapa masalah yang diperoleh dalam pembelajaran.

Penyediaan glosarium pada media pembelajaran ini dapat membantu saya untuk mengetahui istilah yang tak umum ditemukan.

\section{Aspek Materi}

1 Penguraian materi dalam media pembelajaran ini padat dan jelas

Materi yang disajikan dalam media

2 pembelajaran ini sesuai dengan kebutuhan saya

Penyajian contoh video/ simulasi dapat

3 membantu saya untuk lebih memahami materi yang diajarkan.

4 Penggunaan bahasa dalam materi mudah dimengerti.

Jenis dan ukuran huruf yang

5 digunakan dalam materi jelas dan mudah dibaca.

6 Ilustrasi video/ simulasi memberikan informasi yang jelas.

Gambar yang digunakan pada materi

7 sesuai dengan isi materi media pembelajaran

Media pembelajaran ini memuat soalsoal yang dapat menguji seberapa

8 jauh pemahaman saya tentang materi yang terdapat pada mata kuliah Fisika Modern.

9 Materi yang disajikan bermanfaat dan mendorong keingintahuan saya.

Dengan menggunakan media

10 pembelajaran ini membuat belajar saya lebih terarah dan runtut.

\section{Aspek Tampilan}

Jenis dan ukuran huruf yang
digunakan dalam media pembelajaran ini jelas dan mudah dibaca.

Teks atau tulisan yang digunakan

2 dalam media pembelajaran ini jelas dan mudah dipahami.

3 Warna tampilan yang digunakan pada template terlihat menarik.

Gambar yang digunakan pada materi

4 sesuai dengan isi materi media pembelajaran.

Jenis dan ukuran huruf yang

5 digunakan pada halaman depan jelas dan mudah dibaca.

6 Gambar yang digunakan pada tampilan halaman depan jelas dan menarik.

7 Warna yang digunakan pada tampilan halaman depan terlihat menarik.

8 Tampilan media pembelajaran ini menarik.

9 Media pembelajaran ini membuat saya senang mempelajari Fisika Modern.

10 Dengan menggunakan media pembelajaran ini dapat menambah keinginan saya untuk belajar.

Dengan menggunakan media

11 pembelajaran ini dapat membuat belajar Fisika Modern tidak membosankan.

Aspek Pemograman 3,3

3,15
Media pembelajaran ini memberikan

1 kemudahan pada saya dalam pemakaian program.

Media pembelajaran ini memberikan

2 kemudahan memilih menu program.

3 Memberikan saya kebebasan memilih materi untuk dipelajari.

4 Memudahkan saya dalam berinteraksi dengan program.

- Media pembelajaran ini memberikan kemudahan pada saat login.

Materi dapat diulang setiap saat

6 sehingga dapat membantu saya untuk meningkatkan daya ingat.

7 Memberikan kemudahan untuk saya dalam pengaturan pencarian halaman.

Media pembelajaran ini memberi

8 kemudahan pengaturan menjalankan video/animasi.

9 Media pembelajaran ini memberikan kemudahan pada saat logout.

10 Media pembelajaran ini memiliki 2,50 10 kecepatan akses sistem operasi. Jumlah Keseluruhan 3,16

Dari Tabel 5 dapat diketahui tingkat pencapaian yang diperoleh sebesar 3,16 yang menunjukkan bahwa media pembelajaran berbasis e-learning termasuk dalam kriteria baik.

\section{Tampilan Hasil Pengembangan Media}

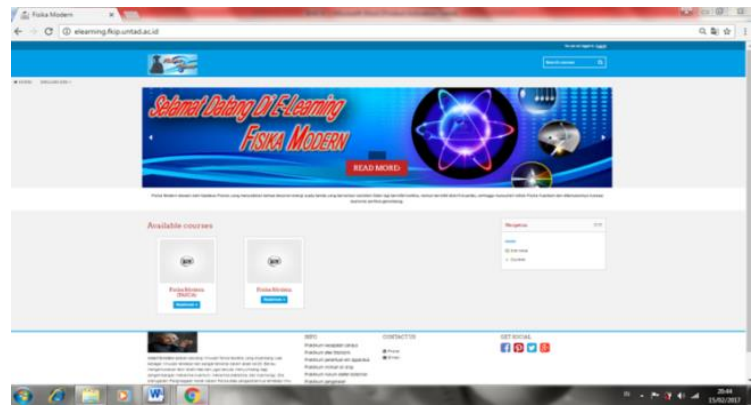

Gbr 2. Tampilan halaman depan (home)

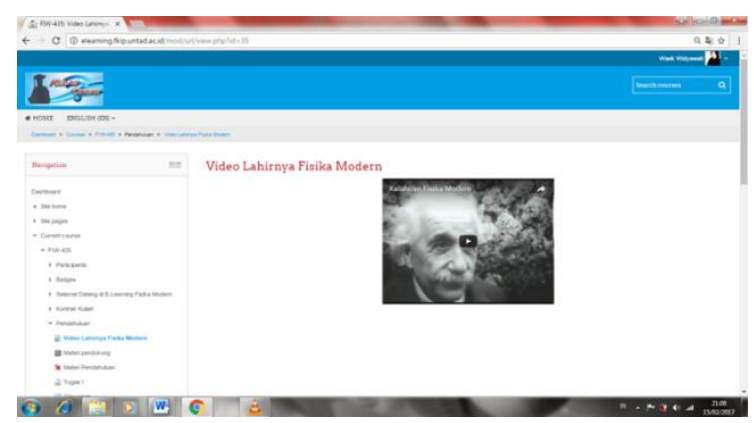

Gbr 3. Tampilan video pada media pembelajaran e-learning

\section{B. Pembahasan}

Penelitian pengembangan media pembelajaran berbasis e-learning pada mata kuliah fisika modern ini bertujuan untuk menghasilkan sebuah media pembelajaran yang bermanfaat dan layak digunakan dalam proses pembelajaran 
fisika, dapat dijadikan alternatif dalam memilih media pembelajaran yang akan digunakan dalam proses belajar mengajar dan diharapkan dapat dijadikan tambahan referensi untuk penelitian selanjutnya tentang pengembangan media pembelajaran berbasis e-learning pada materimateri lainnya. Fungsi dari pembuatan media pembelajaran ini adalah sebagai sumber belajar mandiri dan mempermudah mahasiswa dalam mendapatkan referensi dalam mengerjakan tugas dan dapat memperkaya materi pembelajaran. Pada penelitian ini pengembangan media pembelajaran berbasis e-learning pada mata kuliah fisika modern yang dimaksud adalah suatu kegiatan pembelajaran konvensional yang dituangkan dalam format digital dengan memanfaatkan media situs (website) yang bisa diakses melalui jaringan internet. Media pembelajaran berbasis E-learning ini dibuat untuk mempermudah interaksi antara peserta didik dengan bahan atau materi pelajaran. Media pembelajaran berbasis e-learning ini dikembangkan dengan memanfaatkan modul Content Management Service (CMS) yaitu moodle. Moodle adalah salah satu aplikasi open source yang merupakan paket software yang diproduksi untuk kegiatan belajar berbasis internet dan website, dengan menggunakan Moodle diharapkan dapat meningkatkan efisiensi dan efektivitas kinerja pengajar dan pemahaman pembelajar terhadap materi pembelajaran.

Analisis data hasil pengembangan bahan ajar ini didasarkan pada hasil validasi dan uji coba terbatas. Desain uji coba yang digunakan dalam penelitian ini adalah uji kelayakan terhadap produk. Uji coba dilakukan oleh satu dosen fisika Fakultas MIPA sebagai ahli materi, satu dosen pendidikan fisika sebagai ahli media, serta dua puluh mahasiswa semester V Program Studi Pendidikan Fisika Universitas Tadulako.

Berdasarkan penilaian ahli materi yang dilakukan oleh dosen fisika Fakultas MIPA Universitas Tadulako yaitu ibu Darmawati Darwis, S.Si. M.Si. Ph.D, aspek yang dinilai dari media pembelajaran ini beberapa item dari pokok bahasan masing-masing. Adapun indikator yang di nilai kesesuaian isi materi dengan sub pokok bahasan, kesesuaian gambar pada sub pokok bahasan serta kelengkapan isi materi. Dari hasil uji coba ahli materi diperoleh rata-rata tingkat pencapaian yang diperoleh sebesar 3,72 yang menunjukkan bahwa materi termasuk dalam kriteria "Sangat Baik". Dari hasil tersebut ahli materi menyatakan bahwa media pembelajaran e-learning ini layak diuji cobakan di lapangan dengan revisi.

Hasil penilaian ahli media yang dilakukan oleh dosen pendidikan fisika Universitas Tadulako yaitu bapak I Wayan Darmadi, S.Si. M.Pd, aspek yang dinilai dari media pembelajaran e-learning ini meliputi aspek tampilan media, aspek pembelajaran dan aspek pemograman. Dari hasil uji coba ahli media diperoleh rata-rata tingkat pencapaian pada aspek tampilan media sebesar 3,42 yang dikategorikan sangat baik. Pada aspek pembelajaran, diperoleh rata-rata tingkat pencapaian sebesar 3,00 yang dikategorikan baik. Kemudian pada aspek pemrograman, diperoleh rata-rata tingkat pencapaian sebesar 3,43 yang dikategorikan sangat baik. Secara keseluruhan penilaian dari ahli media diperoleh rata-rata tingkat pencapaian sebesar 3,25 yang menunjukkan bahwa media termasuk dalam kategori "Baik". Dari hasil tersebut ahli media menyatakan bahwa media pembelajaran e-learning ini layak diuji cobakan di lapangan dengan revisi.

Setelah dilakukan validasi ahli media dan ahli materi langkah selanjutnya adalah uji skala kecil atau uji terbatas. Uji terbatas ini bertujuan untuk mengetahui respon mahasiswa terhadap penggunaan media pembelajaran e-learning ini. Media pembelajaran e-learning hasil pengembangan diujikan dalam uji coba lapangan skala kecil kepada 20 mahasiswa. Tujuan pelaksanaan uji coba lapangan skala kecil adalah untuk mendapatkan gambaran respon mahasiswa terhadap media pembelajaran e-learning yang dikembangkan. Mahasiswa memberi tanggapan terhadap aspek pembelajaran, aspek materi, aspek tampilan dan aspek pemrograman dalam media pembelajaran berbasis e-learning. Hasil analisis respon mahasiswa terhadap media pembelajaran berbasis e-learning pada mata kuliah fisika modern yang dikembangkan karena tipe pernyataannya bersifat positif, maka nilai (score) untuk tiap pilihan jawabannya adalah sebagai berikut 4 (Sangat setuju), 3 (Setuju), 2 (Tidak setuju), dan 1 (Sangat tidak setuju). Uji terbatas dilakukan terhadap 20 mahasiswa semester $\mathrm{V}$ Program Studi Pendidikan Fisika Universitas Tadulako, mahasiswa diberi angket yang mempunyai 42 item pernyataan dengan indikator yang dinilai oleh mahasiswa adalah aspek pembelajaran, aspek materi, aspek tampilan dan aspek pemrograman. Setelah melakukan analisis terhadap angket yang diberikan kepada mahasiswa, diperoleh skor rata-rata pada aspek pembelajaran sebesar 3,21 yang dikategorikan baik. Pada aspek materi diperoleh skor rata-rata sebesar 3,17 yang dikategorikan baik. Kemudian pada aspek tampilan diperoleh skor rata-rata sebesar 3,18 yang dikategorikan baik dan pada aspek pemrograman dperoleh skor rata-rata sebesar 3,09 yang dikategorikan baik. Sehingga didapatkan skor rata-rata respon mahasiswa terhadap media pembelajaran berbasis 
e-learning yakni sebesar 3,16. Berdasarkan skor tersebut dapat disimpulkan bahwa penilaian respon siswa terhadap media pembelajaran e-learning ini termasuk ke dalam kategori "Baik". Karena hasil angket menunjukkan kategori "Baik" maka bisa dikatakan bahwa media pembelajaran yang dibuat layak digunakan sebagai media pembelajaran berbasis e-learning.

Media pembelajaran berbasis e-learning ini dikembangkan dengan memanfaatkan modul Content Management Service (CMS) yaitu moodle. Hal ini menjadi salah satu kelebihan dari media pembelajaran e-learning ini. Dengan menggunakan moodle kita dapat mengatur materi pelajaran atau metode pembelajaran seperti berdasarkan minggu, topik atau bentuk diskusi. Media pembelajaran e-learning ini memuat beberapa fasilitas seperti penyediaan video pembelajaran, simulasi, kuis, glosarium, chatting, forum diskusi dan beberapa informasi tambahan yang berkaitan dengan materi pembelajaran dalam bentuk blogspot. Dalam media pembelajaran e-learning ini juga terdapat sebuah fasilitas untuk mempermudah pengajar berinteraksi dengan pembelajar yaitu dengan mempresentasikan sebuah materi pembelajaran dan menjelaskannya secara rinci disertakan suara dan tampilan wajah pengajar sehingga pembelajar lebih memahami materi pembelajaran. Adapun kelebihan lain yang dimiliki media pembelajaran e-learning ini yaitu dapat diakses online dan offline, jadi media pembelajaran e-learning ini bahwa media pembelajaran e-learning ini tidak hanya diakses melalui jaringan internet, namun dapat juga diakses tanpa menggunakan jaringan internet (localhost) dalam sebuah ruangan yang telah disetting untuk berlangsungnya pembelajaran sehingga dapat meningkatkan efisiensi dan efektivitas kinerja pengajar dan pembelajar dalam menggunakan dan memahami materi pembelajaran.

Penelitian pengembangan media pembelajaran e-learning ini secara keseluruhan sudah layak digunakan sesuai dengan penilaian oleh ahli dan mahasiswa serta dapat memudahkan dan membantu mahasiswa dalam memahami materi pembelajaran. Namun hal tersebut tidak lepas dari beberapa kekurangan yang terdapat dalam media pembelajaran e-learning ini dan kendala peneliti saat melakukan penelitian, diantaranya pembelajar membutuhkan jaringan internet yang baik apabila diakses secara online pada saat jarak jauh. Keterbatasan waktu membuat peneliti menggunakan video tentang materi pembelajaran yang telah disediakan di youtobe. Selain itu, dalam membuat media pembelajaran e-learning ini peneliti masih terbatas pada satu mata kuliah saja yaitu mata kuliah fisika modern.

\section{KESIMPULAN DAN SARAN}

\section{A. Kesimpulan}

Berdasarkan analisis dan pembahasan di atas, maka dapat disimpulkan bahwa penelitian pengembangan media pembelajaran berbasis e-learning ini dilakukan berdasarkan langkahlangkah pengembangan yaitu melihat adanya potensi masalah, mengumpulan data, mendesain produk, validasi desain, revisi desain, uji coba produk dan revisi produk. Pada hasil uji coba ahli materi diperoleh skor penilain rata-rata sebesar 3,72 dan dikategorikan "sangat baik", analisis penilaian ahli media diperoleh skor rata-rata sebesar 3,25 dan dikategorikan "baik", sedangkan hasil analisis penilaian respon mahasiswa didapatkan skor rata-rata sebesar 3,16 dan dikategorikan "setuju". Hal ini menunjukkan bahwa media pembelajaran berbasis e-learning sudah layak digunakan dan dijadikan sebagai salah satu media pembelajaran bagi mahasiswa.

\section{B. Saran}

Dengan melihat hasil penelitian yang telah dilakukan, saran yang dapat diberikan pada penelitian ini adalah :

1) Pengajar diharapkan dapat memanfaatkan fungsi pembelajaran berbasis e-learning secara optimal ke dalam proses belajar mengajar agar dapat meningkatkan motivasi belajar peserta didik.

2) Perlu adanya pengembangan media pembelajaran berbasis e-learning pada mata kuliah yang lainnya, untuk menyempurnakan pengadaan media pembelajaran berbasis e-learning di program studi pendidikan fisika FKIP Universitas Tadulako.

3) Melakukan penelitian dan pengembangan lebih lanjut dengan memperbaiki beberapa hal diantaranya, dalam fasilitas video sebaiknya menggunakan video yang dibuat sendiri agar dapat lebih banyak berbagi tentang ilmu pengetahuan yang dimiliki peneliti. Kemudian dalam fasilitas simulasi, dapat membuat simulasi dengan durasi yang lebih lama dan lebih bervariasi misalnya disertakan dengan suara agar peserta didik dapat lebih memahami materi yang disajikan dan menambah minat belajar peserta didik. 


\section{DAFTAR PUSTAKA}

[1] Oetomo, B.S.D dan Priyogutomo, Jarot. (2004). Kajian Terhadap Model E-Media dalam Pembangunan Sistem E-Education. Universitas Ahmad Dahlan Yogyakarta.

[2] Syarif, M. (2012). Pengembangan Media Pembelajaran E-Learning Berbasis Web pada Materi Listrik Dinamis bagi Siswa SMA Kelas $X$ Semester II. Skripsi pada Jurusan Pendidikan Fisika FPMIPA, Universitas Tadulako Palu: tidak diterbitkan.

[3] Hidayat, A. (2008). Pengaruh Penggunaan E-Learning Terhadap Motivasi Siswa dan Efektivitas Pembelajaran Fisika bagi Siswa SMA (Studi Kasus di SMA Negeri 1 Depok). (Online). Tersedia:

http://papers.gunadarma.ac.id/files/journals/7/articles/ 14879/public/14879-41778-1-PB.pdf.
[4] Hamalik, O. (1994). Media Pendidikan. Bandung: Citra Aditya Bhakti.

[5] Sudjana, N. dan Rivai, A. (2002). Media Pengajaran. Bandung : Penerbit C.V.Sinar Baru.

[6] Palupessy, E.T. (2014). Pengembangan Media Pembelajaran Berbasis E-Learning Pada Mata Kuliah Fisika I Untuk Meningkatkan Efektifitas Belajar Mahasiswa. JPTE. Volume 3 Nomor 2 Tahun 2014.

[7] Prakoso, S. (2005). Membangun e-learning Dengan Moodle. Andi Opsett. Jakarta.

[8] Sugiyono. (2010). Metode Penelitian Pendidikan Kuantitatif, kualitatif, dan $R$ \& D. Bandung : Alfabeta.

[9] Arikunto, S. (2006). Prosedur Penelitian: Suatu Pendekatan Praktik. Jakarta: Bineka Cipta.

[10] Widoyoko. (2012). Teknik Penyusunan Instrumens Penelitian. Yogyakarta: Pustaka Pelajar. 